a non-ozone-depleting refrigerant in the design of an energy-efficient refrigerator. In addition to the modules, the NPPC is currently creating a network of faculty and programmes around the country which are involved in integrating pollution prevention concepts into curricula. This Directory of Pollution Prevention in Higher Education: Faculty and Programs, 1992 is also available from the Center (US faculty no charge, others US $\$ 4.50+$ shipping).

The NPPC's creation and development of educational materials on pollution prevention is a cyclical process. The modules are continually being made, used, reviewed, and updated in such a way as to remain applicable to our changing society. The use of our resources by faculty members and other staff is critical to achieving the
NPPC's goal of widespread pollution prevention education.

If you are interested in more information on the Center, please contact Dr Gregory A. Keoleian, Center Manager at the address given below or telephone (313) 764-1412, or Fax (313) 936-2195.

\author{
Vera Siguel \\ National Pollution Prevention Center \\ for Higher Education \\ 430 East University Avenue \\ Dana Building 2540 \\ Ann Arbor \\ Michigan 48109-1115 \\ USA.
}

\title{
Global Distinction for INSONA's Environmental Awareness
}

$\mathrm{T}$ he quarterly journal Environmental Awareness, organ of the International Society of Naturalists (INSONA), with headquarters in Baroda, India, has achieved a rare and possibly unique record of having eleven United Nations Environment Programme (UNEP) 'Global 500' Laureates on its Board of Consulting Editors. They were chosen for the Awards, during 1987 to 1992, for outstanding achievements in the protection and improvement of the environment.

The recognized celebrities who have excelled in the main fields of environmental endeavour and who figure on the UNEP's Roll of Honour include Senator Professor Mohamed Kassas (Egypt) and Maurice F. Strong (Canada) for 1987; Professor Norman Myers (England, UK) for 1988; Professor Paul R. Ehrlich (USA) for 1989; Professor Gunavantrai Oza (India) and Dr Arthur $\mathrm{H}$. Westing (USA) for 1990; Professor Lynton K. Caldwell (USA) and Professor Nicholas Polunin (Switzerland) for 1991; Dr Mrs Shirley McGreal (USA), Professor Vo Quy (Vietnam), and M. A. Partha Sarathy (India), for 1992.

Environmental Awareness is devoted to the cause of environmental conservation for human welfare. Founded in the year 1977 and edited throughout by the undersigned, the journal is thought to have been the first of its kind to become established in any Asian or African country, and is well-received among international nongovernmental organizations (INGOS) (Oza, 1987, $1989 a$ ).

It is yet another matter of distinction that the abovementioned 'eleven' are among the distinguished adherents of now 28 mostly internationally-known leaders in the environmental movement to constitute the Panel of Consulting Editors of Environmental Awareness (Oza,
$1989 b$ ). They include (in alphabetical order of family names) William C. Burns (USA), Professor Raymond F. Dasmann (USA), Richard Fitter (England, UK), Dr Walter D.S. Leal Filho (Brazil), Dr F. Raymond Fosberg (USA), Dr Thor Heyerdahl (Norway), Grenville Lucas (UK), Dr Walter J. Lusigi (Kenya), Professor Makoto Numata (Japan), Mrs Premlata Oza (India), Dr Mrs Mrunalinidevi A. Puar (India), Dr George B. Rabb (USA), Dr S. Dillon Ripley (USA), Professor Richard E. Schultes (USA), Dr Monkombu Swaminathan (India), Dr Lee M. Talbot (USA), and Dr John R. Vallentyne (Canada).*

\section{REFERENCES}

OzA, G.M. (1987). INSONA and Environmental Awareness. Environmental Conservation, 14(2), p. 181, 2 figs.

OZA, G.M. (1989a). INSONA changes thrust and name to International Society of Naturalists. Environmental Conservation, 16(3), pp. 271-2.

OZA, G.M. (1989b). Environmental Awareness benefits. Environmental Conservation, 16(3), p. 367.

Gunavant M. Oza, Professor of Botany, The Maharaja Sayajirao University of Baroda; General Secretary of INSONA \& Founding Editor of Environmental Awareness Oza Building, Salatwada, Baroda 390001 , India.

* In our considered opinion, several of these merit Global 500 A wards and to our knowledge one has latterly been nominated while at least six more will be in due course if (as is much to be hoped) this honouring distinction is extended and provided we are invited again to nominate and are spared to do so. - Ed.

\section{Ozone Depletion Over Antarctica Returns}

$\mathrm{T}$ he depletion of ozone returned with vigour over the sunlit regions of the Antarctic at the beginning of the second ten-days' period of August 1993. This was revealed by the World Meteorological Organization (WMO) through its bulletins on the state of the ozone layer which are issued annually during the August/ November period. The first of these this year was issued in Geneva on August 30th.

During the preceding four weeks, total ozone values had fallen from a normal of $310 \mathrm{~m}$ atm $\mathrm{cm}^{*}$ down to about

$* \mathrm{~m} \operatorname{atm} \mathrm{cm}=.001$ atmosphere pressure centimetre. or below $200 \mathrm{~m}$ atm $\mathrm{cm}$ - a decline of over $35 \%$. This decline had commenced at least three weeks earlier than was observed in the mid-1980s and is a few days earlier than the unprecedented events of 1992, when the earlieststarting depletion, to the lowest-observed values and covering the largest area ever, was recorded, stated Dr Rumen D. Bojkov, Special Adviser to WMO's SecretaryGeneral on the Ozone and Global Environmental Issues.

\section{Ozone 'Hole' Annual}

Based on the data provided by Members of the World Meteorological Organization who participate in the 
Global Ozone Observing System that includes groundbased stations and specialized satellites (e.g. NASATOMS/Meteor and NOAA-TOVS), it is now well-known that, since the late 1970 s, every September-October a reduction of stratospheric ozone is observed over the Antarctic which accelerates during September and reaches the lowest ozone values in the first part of October, thus generating the so-called 'ozone hole' in the stratosphere. Thorough analysis of observed data, complemented by laboratory and modelling studies, indicates that the cause of this ozone 'hole' is the chlorine and bromine released by Man-made chemical compounds such as the chlorofluorocarbons (CFCs) and halons.

The presence of these chemicals, combined with ideal conditions that are unique to the Antarctic Austral Spring - the closed atmospheric circulation vortex isolated from major south-north meridional exchanges, the extremely low stratospheric temperatures (below $-80^{\circ} \mathrm{C}$ ), and the existence of aerosols - create a situation which is conducive to rapid ozone destruction. For five of the past six years, the ozone at altitudes between 14 and 20 kilometres has been almost totally annihilated during late September and into October. Besides the hazards to human health, continued depletion of the ozone shield could have some negative effects on crop yields and aquatic life as well as in changing the radiative regime of the Earth's atmosphere. However, in accordance with decisions agreed to under the Montreal Protocol coordinated by UNEP, measures are being taken to eliminate production and use of substances which cause ozone depletion.

During the last Antarctic Austral Spring season (1992) the ozone 'hole' appeared in the second half of August, reached its greatest-size-ever of approximately 25 million square kilometres, and in October recorded the lowest ozone values ever of about $110 \mathrm{~m}$ atm $\mathrm{cm}$ compared with $330 \mathrm{~m}$ atm $\mathrm{cm}$ averages for the same month in the years prior to ozone-hole detection.

\section{Showing}

This year from the beginning of August total ozone over the Antarctic has already fallen by 110 units or about $35 \%$ below that of the pre-ozone-hole-detection average. Ozone soundings from the German station Neumayer $\left(70^{\circ} \mathrm{S}\right)$, at altitudes of 16 to $20 \mathrm{~km}$ where temperatures are below $-85^{\circ} \mathrm{C}$, indicate ozone loss of over $50 \%$ in that layer. This is collaborated by ozone soundings at $\mathrm{Ma}-$ rambio $\left(64^{\circ} \mathrm{S}\right)$ and Syowa $\left(69^{\circ} \mathrm{S}\right)$. Around 10-12 August, ozone values measured over the Palmer Peninsula were lower than $180 \mathrm{~m}$ atm $\mathrm{cm}$, and during the third 10 days' period of the month, in both the NW and the NE sectors, reports were of similar low values. Over the ocean sector of the middle latitudes, between the Antarctic coast and Southern Africa-Australia-New Zealand in a crescentshaped region, relatively high ozone dominates, with a maximum of about $400 \mathrm{~m}$ atm $\mathrm{cm}$, which values are only 5 to $10 \%$ below what was formerly normal.

Dr Bojkov concluded that all these data indicate that not only is the ozone depletion in progress, but also that in this Antarctic Austral Spring, if the stratospheric circulation keeps the vortex intact and very cold temperatures persist, we could expect, in September-October, extremely low ozone values similar to those of last year.

InFORMATION AND PUBLIC AfFaIRS OfFICE World Meteorological Organization

PO Box 2300

1211 Geneva 2

Switzerland.

\section{ProMED Mission Statement: The Federation of American Scientists' Programme for Monitoring Emerging Diseases}

$\mathrm{N}$ umerous recent episodes of emerging and re-emerging infections - including AIDS, the continuing spread of dengue viruses, multi-drug-resistant tuberculosis and other antibiotic-resistant Bacteria, cholera in Africa and South America, and the resurgence of measles in US cities - attest to Humans' continuing vulnerability to infectious diseases throughout the world. Many experts, both within and outside government, have warned of the need to improve capabilities for dealing with emerging infectious diseases. A recent report from the Institute of Medicine of the US National Academy of Sciences declared:

'Disease-causing microbes have threatened human health for centuries. ... [The Committee] believes that this threat will continue and may even intensify during the coming years. ... Infectious diseases remain the major cause of death worldwide. ...the next major infectious agent to emerge as a threat to health in the United States may, like HIV, be a pathogen that has not been previously recognized. ...The key to recognizing new or emerging infectious diseases, and to tracking the prevalence of more established ones, is surveillance.

The need to monitor and control the global spread of infectious diseases has become critical as new diseases, or formerly obscure or geographically isolated diseases, spread rapidly across the globe. These diseases often appear first in tropical countries and areas of civil conflict from which, if not recognized and contained, they may spread globally, aided by large-scale population movements or environmental destruction. During the last two decades, more than a dozen new viral diseases and drugresistant pathogens affecting humans have been identified, yet during this same period of time, money for research, disease surveillance, and reporting systems, has been cut.

The development of a global infectious-disease surveillance system has been the primary recommendation of expert analyses, including the Institute of Medicine report. A programme to identify and quickly respond to unusual outbreaks of infectious diseases, to prevent their spread, would be highly beneficial - not only to the region of origin, but to the rest of the world as well. Unfortunately, existing international structures to monitor and contain infectious disease outbreaks are poorly coordinated and understaffed. International structures are also inadequate for the containment and monitoring of animal and plant diseases, which could threaten food supplies and, in some cases, could infect humans.

The value of a cooperative international health project as an incentive for a strengthened Biological Weapons 